\title{
GROUND WATER OF THE PIEDMONT \\ AND BLUE RIDGE PROVINCES \\ IN THE SOUTHEASTERN STATES
}

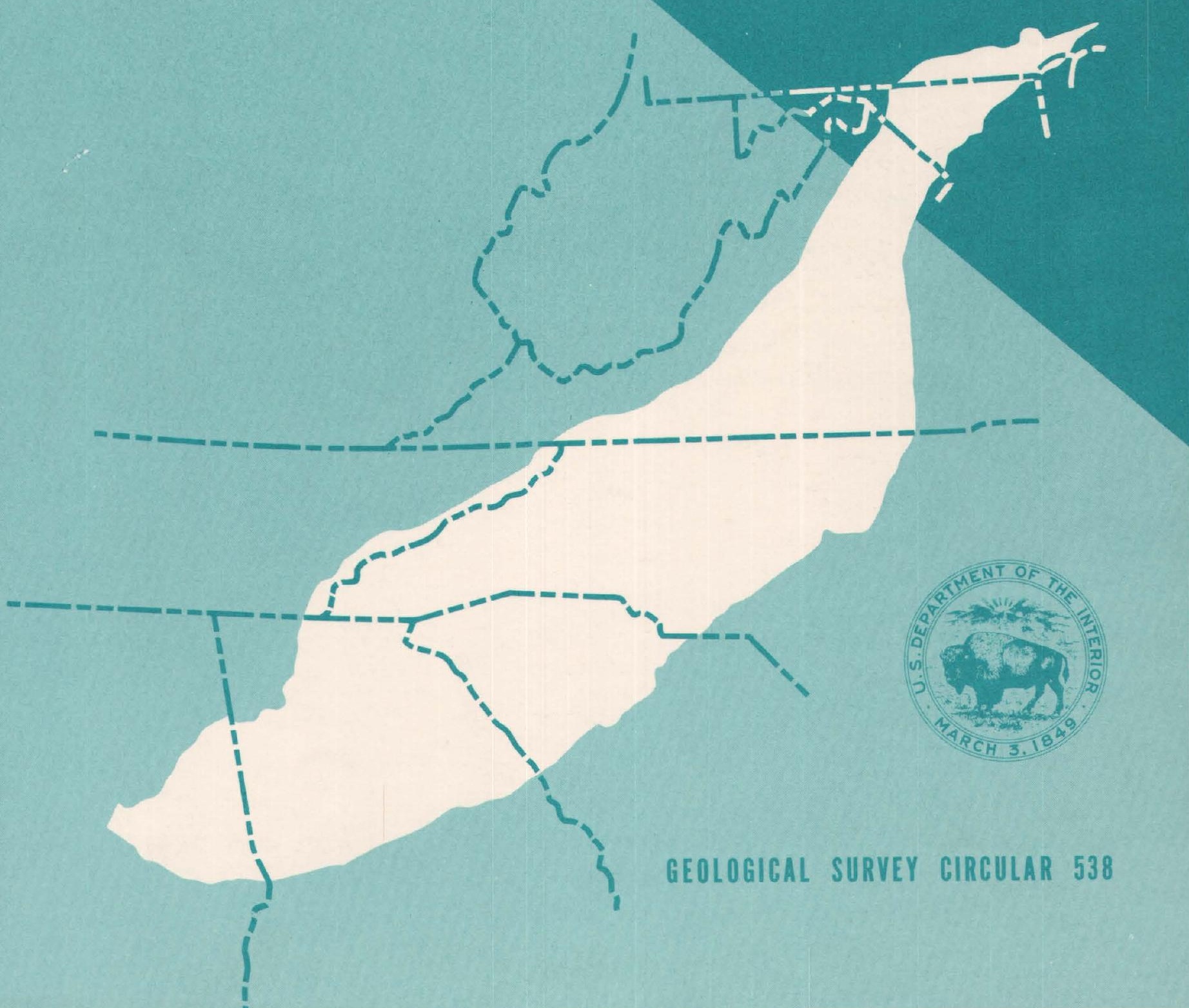





\section{Ground Water of the Piedmont and Blue Ridge Provinces in the Southeastern States}

By H. E. LeGrand

GEOLOGICAL SURVEY CIRCULAR 538

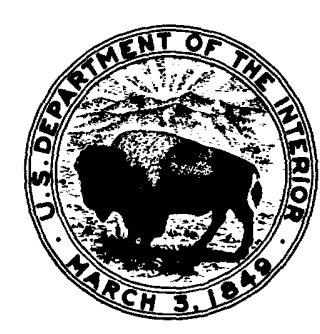




\section{United States Department of the Interior}

ROGERS C. B. MORTON, Secretary

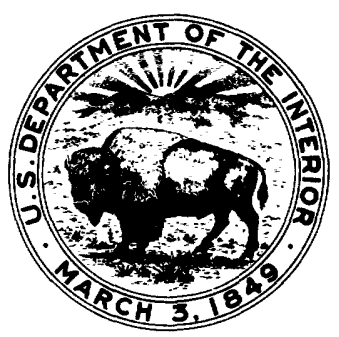

\section{Geological Survey}

v. E. McKelvey, Director

First printing 1967

Second printing 1973

Free on application to the U.S. Geological Survey, Washington, D.C. 20244 


\section{CONTENTS}

Page

Introduction .......... 1

Chemical quality of the water.....

Page

Evaluating sites .

Yield _................ 4

Contamination of ground water....... 8

Depth of wells

General statements about ground water in the region

Fractures in the rock

Sources of information.......... 11

Water table

\section{IL $\overline{\text { LUSTRATIONS }}$}

Figure 1. Generalized geologic map

2. Topographic map and profiles of ground surface showing rating in points for topographic positions

3. Graph showing rating in points for soil thickness

4. Graph showing probability of getting a certain yield from a well at different sites ..........

5. Photograph of countryside in the Blue Ridge province showing approximate ratings for topography

6. Photograph showing area where soil zone is likely very thin

7. Curve showing relation of yield to drawdown

8. Diagram showing yield of a well at two different pumping rates . .

9. Diagram showing extent to which deepening of average well increases yield --

10. Sketches of six types of ground conditions showing distribution of fractures --

11. Hydrograph shows that the water table generally declines in summer and fall

12. Sketch of dry zone lifted up to show water table

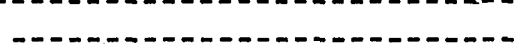

\section{TABLES}

Table 1. Use of numerical rating of well site to estimate the percent chance

2. Concentrations of chemical constituents and their characteristic effects on water use in the region 



\title{
Ground Water of the Piedmont and Blue Ridge Provinces in the Southeastern States
}

\author{
By H. E. LeGrand
}

\section{INTRODUCTION}

This circular summarizes the underground water conditions in the Piedmont and Blue Ridge provinces of the Southeastern Statesthe region shown on the geologic map (fig. 1).

There are several ways of developing water from the ground in this region. In earlier days springs were used because they are common in coves or on lowland slopes. Almost all springs in the region yield between $\frac{1}{2}$ to 3 gallons per minute and rarely show a significant decline in yield during dry weather. Dug wells were common in the past, but they are being replaced by bored and drilled wells. Bored wells, like dug wells, are as much as 2 feet in

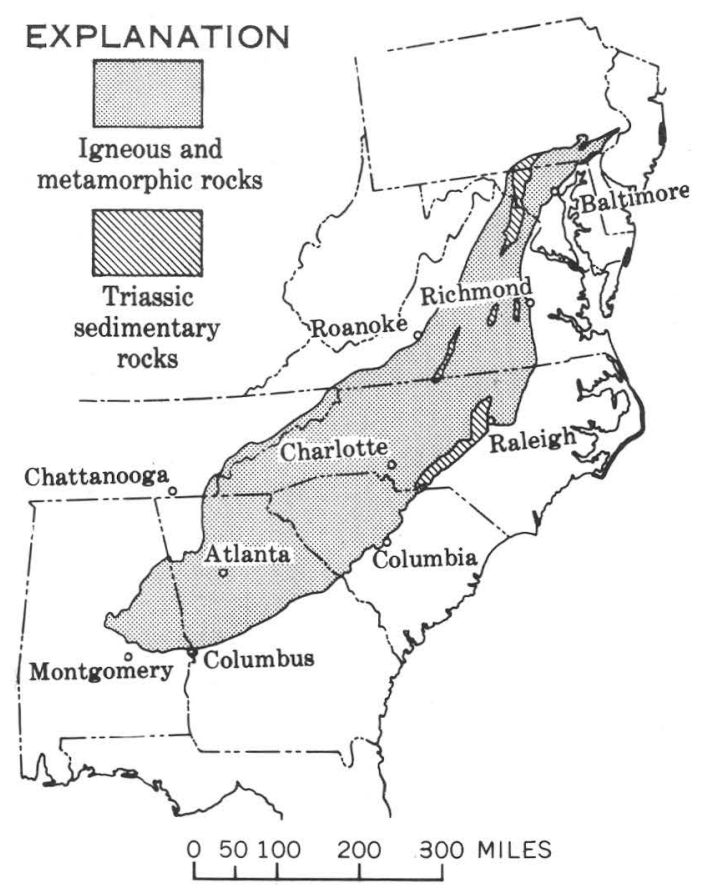

Figure 1. - Generalized geologic map. Areas underlain by igneous and metamorphic rocks are better suited to numerical rating of well sites than areas underlain by Triassic sedimentary rocks. diameter and are commonly lined with concrete or terra cotta pipe; these wells do not extend into hard rock and go dry if the water table falls below the bottom of the well. Drilled wells, which are now the most common source of ground-water supply and which are the chief concern of this report, are cased to the hard rock and extend as open holes into the rock. Although some drilled wells are as small as 2 inches in diameter and others are as large as 10 inches, the most common size is about 5 or 6 inches. Almost every well in recent years has been properly constructed to prevent water on the ground from running down the outside of the casing into the well.

\section{EVALUATING SITES}

A special attempt is made to help those who are interested in the yields of wells. Because yields of individual wells in the region vary greatly within distances as short as 100 feet, estimates of potential yields of prospective wells are difficult to make. This fact has led frequently to water shortages, excessive costs, inconveniences, or undue anxiety in many cases. As the yield of a well is unpredictable, the next best approach is to attempt to show, on a percentage basis, the chance for a certain yield from a well for different conditions.

Although many factors determine the yield of a well, two ground conditions, when used together, serve as a good index for rating a well site. These conditions are topography and soil thickness. The ratings are based on the following statement: High-yielding wells are common where thick residual soils and relatively low topographic areas are combined, and low-yielding wells are common where thin soils and hilltops are combined. By comparing conditions of a site according to the topographic and soil conditions one gets a relative 
rating value. For example, the following topographic conditions are assigned point values:

Points

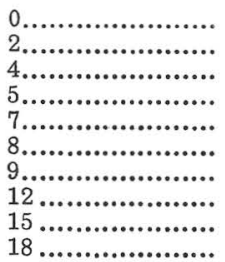

Topogiraphy

Steep ridge top

Upland steep slope

Pronounced rounded upland

Midpoint ridge slope

Gentle upland slope

Broad flat upland

Lower part of upland slope

Valley bottom or flood plain

Draw in narrow catchment area

Draw in large catchment area

Figure 2 shows values for certain topographic conditions. Figure 3 shows rating values for soil thickness. The soil zone in this report includes the normal soils and also the relatively soft or weathered rock. The topographic conditions and soil conditions are separately rated, and the points for each are added to get the total points which may be used in table 1 to rate a site.

Using two well sites, $A$ and $B$, as examples, we can evaluate each as to the potential yield of a well. Site A, a pronounced rounded upland (4-point rating for topography in fig. 2) having a relatively thin soil (6-point rating for soil characteristic in fig. 3), has a total of 10 points. In table 1 the average yield for site $A$ is $6 \mathrm{gpm}$ (gallons per minute). This site has a 65 -percent chance of yielding $3 \mathrm{gpm}$ and a $40-$ percent chance of yielding $10 \mathrm{gpm}$. Site $\mathrm{B}, \mathrm{a}$
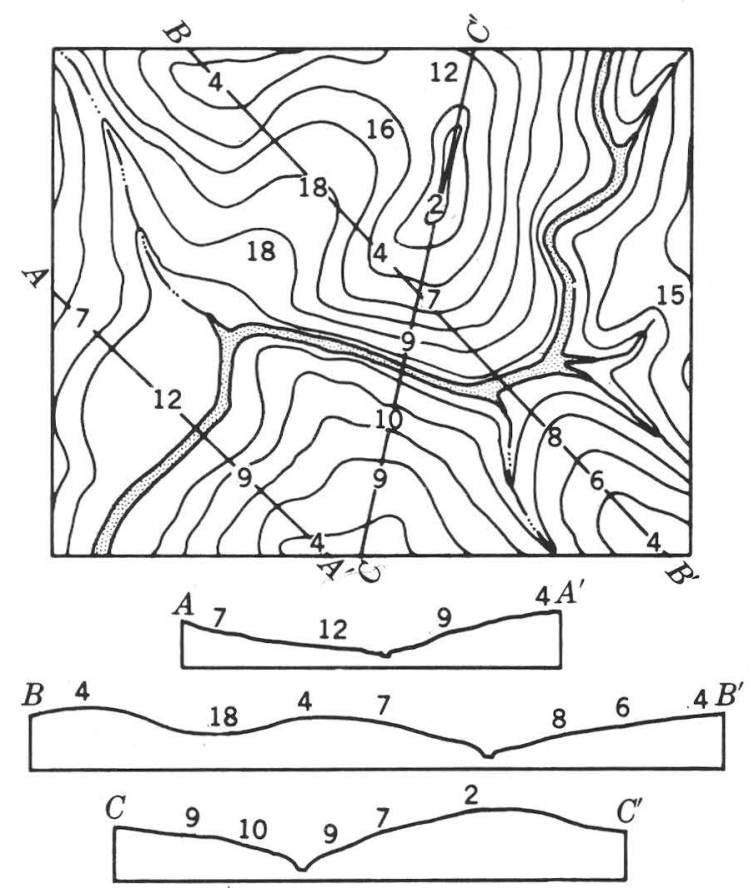

Figure 2.-Topographic map and profiles of ground surface showing rating in points for various topographic positions.

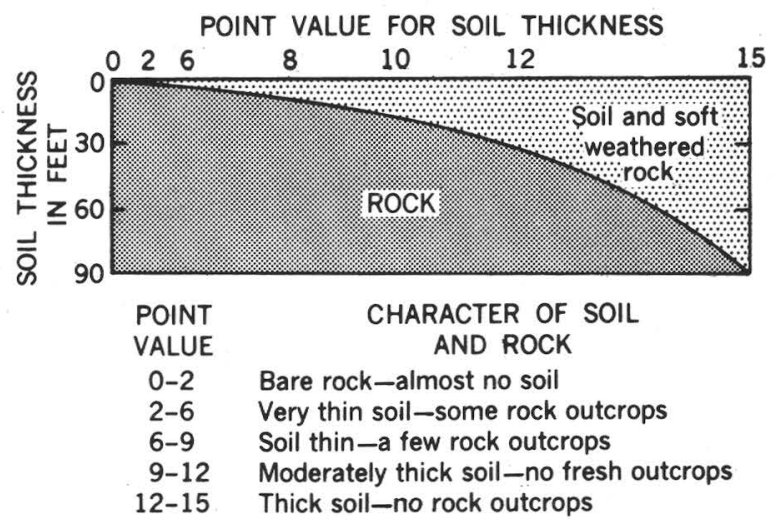

Figure 3. - Rating in points for various conditions of soil thickness.

Table 1.-Use of numerical rating of well site to estimate the percent chance of success of a well

[Data are based on maximum depth of 300 feet or maximum drawdown of water level of about 200 feet. No interference from pumping is assumed. Numerical rating is obtained by adding rating in points for topography and soil thickness]

\begin{tabular}{|c|c|c|c|c|c|c|}
\hline \multirow{2}{*}{$\begin{array}{c}\text { Total } \\
\text { points } \\
\text { of a } \\
\text { site }\end{array}$} & \multirow{2}{*}{$\begin{array}{c}\text { Aver- } \\
\text { age } \\
\text { yield } \\
(\mathrm{gpm})\end{array}$} & \multicolumn{5}{|c|}{$\begin{array}{c}\text { Chance of success, in percent, for } \\
\text { a well to yield at least- }\end{array}$} \\
\hline & & $3 \mathrm{gpm}$ & $10 \mathrm{gpm}$ & $25 \mathrm{gpm}$ & $50 \mathrm{gpm}$ & $75 \mathrm{gpm}$ \\
\hline 5 & 2 & 48 & 18 & 6 & 2 & $\ldots$ \\
\hline 6 & 3 & 50 & 20 & 7 & 3 & $\ldots \ldots$ \\
\hline 7 & 3 & 55 & 25 & 8 & 3 & $\ldots . . .$. \\
\hline 8 & 4 & 55 & 30 & 11 & 3 & $\ldots$ \\
\hline 9 & 5 & 60 & 35 & 12 & 4 & $\ldots$ \\
\hline 10 & 6 & 65 & 40 & 15 & 5 & $\ldots$ \\
\hline 11 & 7 & 70 & 43 & 19 & 7 & ..... \\
\hline 12 & 9 & 73 & 46 & 22 & 10 & ...... \\
\hline 13 & 11 & 77 & 50 & 26 & 12 & ...... \\
\hline 14 & 12 & 80 & 52 & 30 & 14 & ...... \\
\hline 15 & 14 & 83 & 54 & 33 & 16 & 1..-n \\
\hline 16 & 16 & 85 & 57 & 36 & 18 & $\ldots$ \\
\hline 17 & 17 & 86 & 60 & 40 & 20 & 12 \\
\hline 18 & 20 & 87 & 63 & 45 & 24 & 15 \\
\hline 19 & 23 & 88 & 66 & 50 & 25 & 18 \\
\hline 20 & 26 & 89 & 70 & 52 & 27 & 20 \\
\hline 21 & 28 & 90 & 72 & 54 & 30 & 22 \\
\hline 22 & 31 & 91 & 74 & 56 & 35 & 24 \\
\hline 23 & 34 & 92 & 76 & 58 & 38 & 26 \\
\hline 24 & 37 & 92 & 78 & 60 & 40 & 29 \\
\hline 25 & 39 & 93 & 80 & 62 & 43 & 32 \\
\hline 26 & 41 & 93 & 81 & 64 & 46 & 36 \\
\hline 27 & 43 & 94 & 82 & 66 & 48 & 40 \\
\hline 28 & 45 & 95 & 83 & 68 & 50 & 42 \\
\hline 29 & 46 & 95 & 84 & 71 & 53 & 44 \\
\hline 30 & 50 & 96 & 87 & 73 & 56 & 47 \\
\hline $30+$ & 50 & 97 & 91 & 75 & 60 & 50 \\
\hline
\end{tabular}




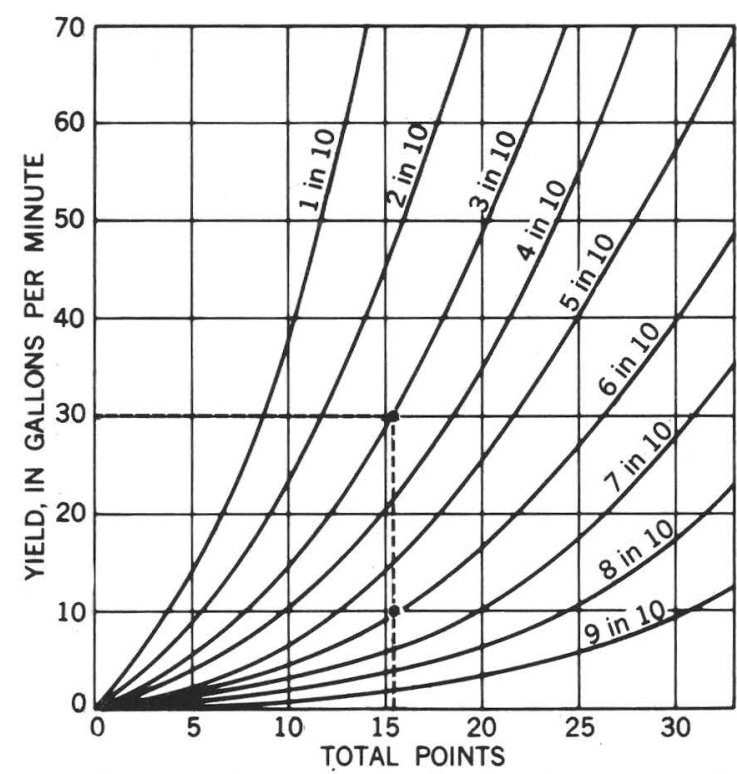

Example: A site with 16 points has 3 chances in 10 of yielding at least 30 gallons per minute and 6 chances in 10 of yielding 10 gallons per minute

Figure 4.-Probability of getting a certain yield from a well at different sites having various total-point ratings. draw or slight sag in topography (18-point rating) having a moderately thick soil (12point rating), has a total of 30 points, an average yield of $50 \mathrm{gpm}$, and a 73-percent chance of yielding $25 \mathrm{gpm}$. Referring to figure 4 , we see that the 10-point site has less than 1 chance in 10 of yielding $40 \mathrm{gpm}$ whereas the 30 -point site has better than an even chance of yielding $40 \mathrm{gpm}$.

Some topographic conditions of the region and a few topographic ratings are shown in figure 5. Wells located on concave slopes are commonly more productive than wells on convex slopes or straight slopes. Broad but slight concave slopes near saddles in gently rolling upland areas are especially good sites for potentially high-yielding wells. On the other hand, steep V-shaped valleys of the gully type may not be especially good sites, and they should be avoided if surface drainage near the well is so poor that contamination is possible.

More difficulty is likely to occur in rating character of soil and rock than in rating

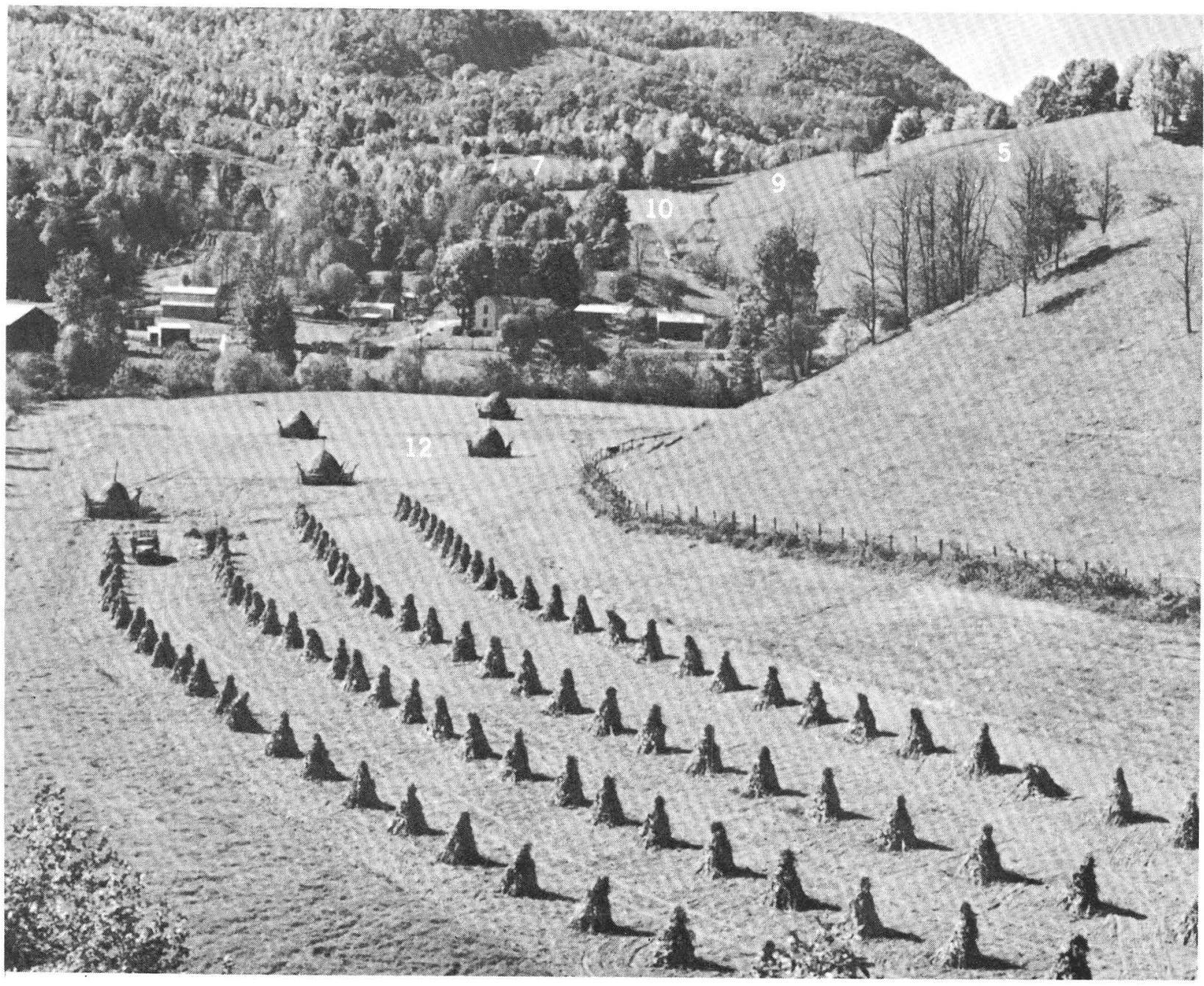

Figure 5.-Countryside in the Blue Ridge province showing approximate ratings for topography. 


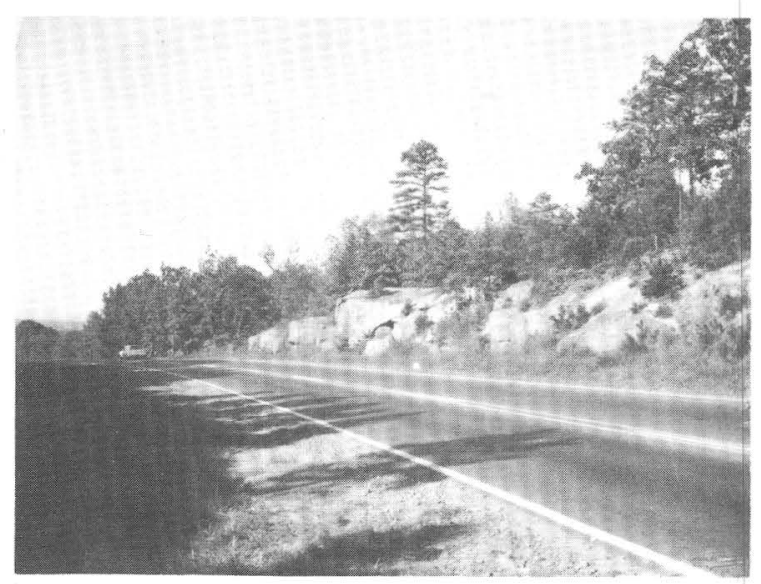

Figure 6.-The soil zone is likely very thin near these rock outcrops (soil-thickness rating 0 to 4 points).

topography. Everyone should be able to determine by observation if the soil is thin (less than 7 soil and rock points as shown in figure 6 ) and if the soil is fairly thick (more than 10 soil and rock points), but the intermediate ratings are difficult to make. If the observer is unsure of the soil and rock rating above the 6 -point (thin soil) value he may choose a 10point value for the site with assurance that he is fairly correct. White quartz of flint, which occurs as veins and as rock fragments on the ground, is not considered a true rock in this report because it persists in the soil zone; a quartz vein in many cases is considered to be a slightly favorable indication of a good well site.

The numerical rating system is not intended to be precise. One person may rate a particular site at 15 points, whereas another person may rate it at 17 points; such a small difference in rating would not be misleading. Almost everyone's rating will be within 5 points of an average rating for a site.

\section{YIELD}

The term "yield" is not definite but is the reported capacity of a well to produce water, generally during a short pumping test. The water level in a well will stabilize if a certain limited yield or withdrawal of water is maintained; however, a greater withdrawal or yield will cause the water level to fall. In many cases the water level continues to fall until the pumping stops so that continuous pumping would result in a smaller yield than that estimated earlier. The percentage of relative yield is not directly proportionate to the percentage of drawdown of the water level, but the greater percentage of yield is reached before the greater percentage of drawdown. Figure 7 shows an approximate relation of drawdown to yield for an average well in the region. Note that the yield-drawdown relationships of all wells lie within the shaded zone and that average conditions occur on or near the heavy line. As an example of the relation between yield and drawdown, we may consider a well 220 feet deep having a static water level of 20 feet below land surface. (See fig. 8.) This well yields $40 \mathrm{gpm}$ with a pumping level at a depth of nearly 220 feet; the pump might better be set at 120 feet (50 percent of drawdown or half the thickness of the water) where about $36 \mathrm{gpm}$ or 90 percent of the relative yield could be realized. It is unnecessary and uneconomical to lower the water level of a well to a position near the bottom unless the yield is so poor that the water stored in the well is needed.

There is no simple definition of the yield of a well-especially in the Blue Ridge and Piedmont provinces. Yields for various levels of the water in the pumped well are rarely known. The yields in this report are considered to be standard for wells about 300 feet deep which are pumped about 12 hours each day and in which drawdown of the water level is about 200 feet; it is assumed that there is no interference by pumping from other wells, which would increase drawdown.

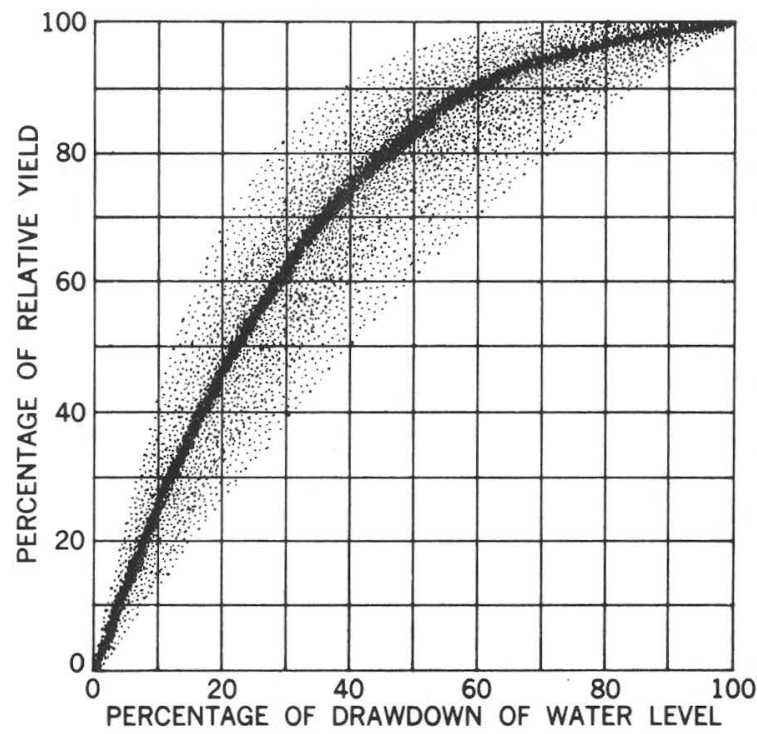

Figure 7. - The curve shows that an increase in yield of a well is not directly proportionate to an increase in drawdown of the water level. A yield of nearly 80 percent of the total capacity of a well results from lowering the water level only 40 percent of the available drawdown. 


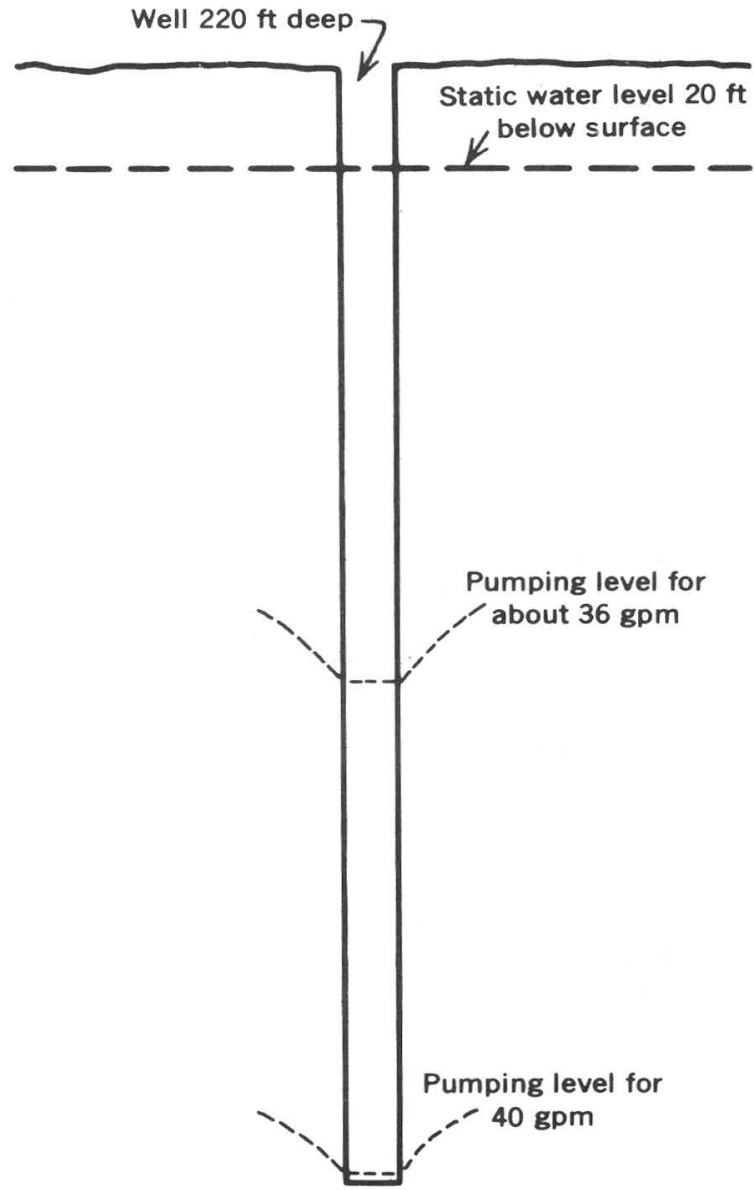

Figure 8. -Yield of a well at two different pumping rates.

\section{DEPTH OF WELLS}

How deep should a well be drilled? This question is not easy to answer for an individual well. In most places fractures in the rock get smaller and fewer with depth and deep drilling may not be economical. Figure 9 shows the percentage of total yield for certain depths in an average well.

The following table shows the percentage of wells that reach their maximum yields at certain depths below which drilling is useless. As

\begin{tabular}{|c|c|}
\hline $\begin{array}{l}\text { Depth } \\
\text { (feet) }\end{array}$ & $\begin{array}{c}\text { Percentage } \\
\text { of wells }\end{array}$ \\
\hline 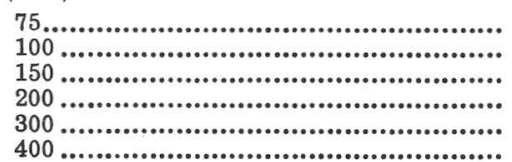 & $\begin{array}{l}25 \\
30 \\
50 \\
70 \\
85 \\
93\end{array}$ \\
\hline
\end{tabular}

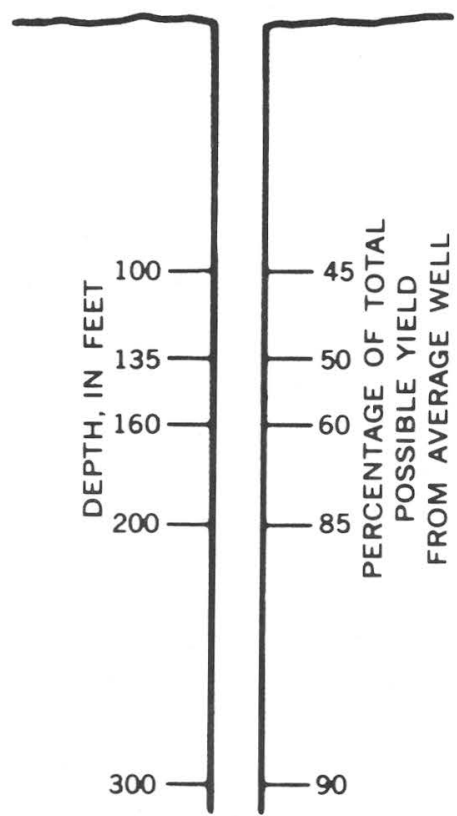

Figure 9.-Extent to which deepening of average well increases the yield.

most of the interconnecting fractures occur in a zone no deeper than 150 feet below the land surface, it may be wise to drill no deeper than 150 feet if the yield is very poor, or no deeper than 300 feet in almost all cases.

\section{FRACTURES IN THE ROCK}

Figure 10 illustrates six different fracture patterns in rocks penetrated by wells. To simplify the illustrations the water table and soil thickness are considered uniform, and each well, cased to 50 feet, is 250 feet deep. The approximate number of times each general pattern of fractures occurs in 100 wells is shown in percentage beneath each type. Well A penetrates no fractures below the casing; therefore, the well yields no water. Well $B$ penetrates a fracture zone in which two or more fractures occur a few feet below the casing. This type of well is common. It may yield as much as 10 to $20 \mathrm{gpm}$ for a period of several minutes until the fractures are drained. Then its yield will likely decline sudden$l y$, and the amount of decline will depend upon the amount of water transmitted to the well by the soil and the underlying thin zone of fractured rock. That part of the well below the fracture zone contributes no water and acts only as a storage reservoir into which water drains. The yield of this well does not increase with increased drawdown. Well $\mathrm{C}$ penetrates only one fracture, a large one near the 

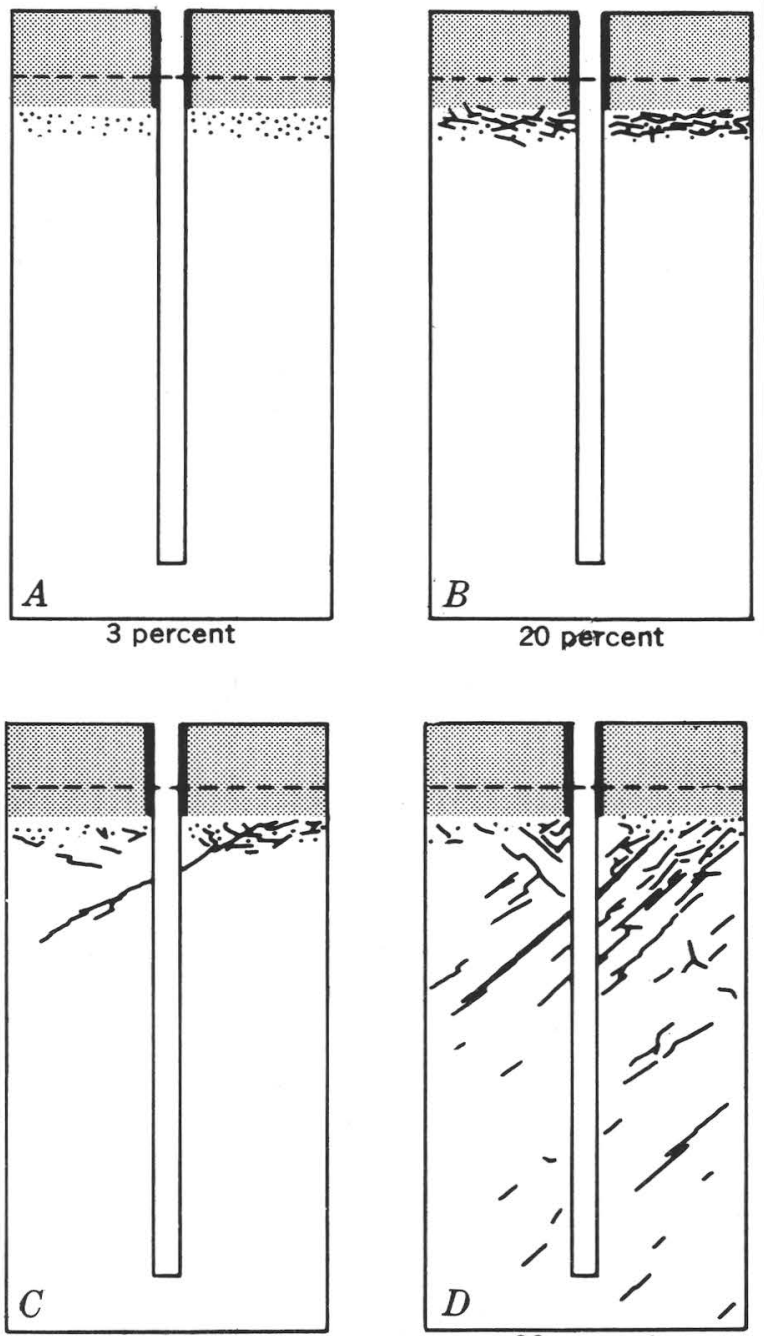

15 percent
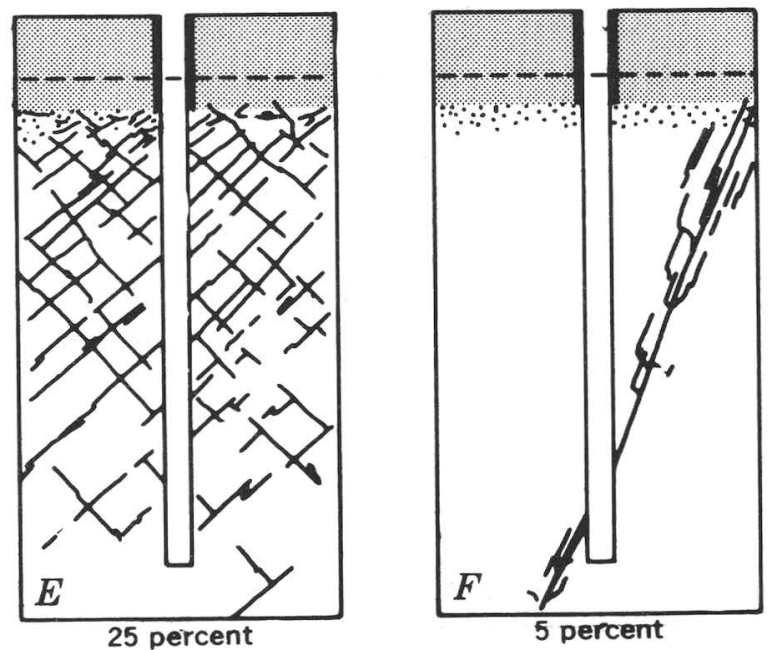

Figure 10.-Six types of ground conditions showing distribution of fractures that influence the yields of wells. The stippled pattern represents soil and soft rock; the dashed line is the water table. The degree of frequency of the different types is shown in percentage. top of the fresh rock. This well is similar to well B. It may yield considerable water for a few minutes until the stored water in the fraccure is drained. The perennial yield, under continuous pumping, will depend on the permeability of the soil and weathered rock and on the amount of water that is released to the fracture. Well D penetrates several fractures, which contribute small amounts of water, and a large fracture at a depth of about 90 feet. Well $\mathrm{E}$ penetrates several small - to mediumsized fractures. These fractures are larger and more closely spaced in the upper part of the bedrock. Well. F penetrates only one fracture-a large one below a depth of 200 feet.

\section{WATER TABLE}

The water table, or upper surface of the underground reservoir, continuously fluctuates and reflects changes in underground storage. During droughts we see evidence of a falling water table when many shallow wells go dry. We also can detect a lowering of the water table locally around wells from which water is pumped. There is a continual discharge of ground water by seepage into streams, by evaporation, and by transpiration through vegetation. The discharge causes a gradual lowering of the water table except for periods during and immediately after significant precipitation when recharge to the underground reservoir exceeds the discharge from it and the water table rises. Figure 11 shows the trends of water-level fluctuation in a well at Chapel Hill, N. C. The water level in this well is controlled entirely by natural conditions, and its fluctuation is typical of that in the region. There is a characteristic seasonal change in the water table, which begins to decline in April or May owing to the increasing amount of evaporation and transpiration of plants. In November or December, when much of the vegetation has become dormant, the precipitation first makes up the summertime soil-moisture deficiency and then again becomes effective in producing recharge, and the water table begins to rise. In a year of normal rainfall the recharge to the underground reservoir is approximately equal to the discharge from it, so that the water table

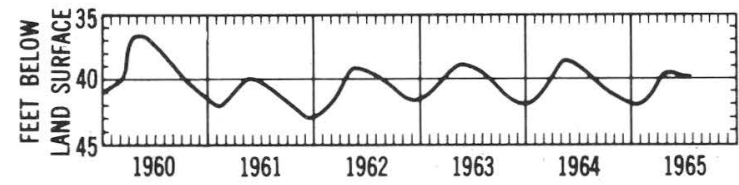

Figure 11. - The water table generally declines in summer and fall but rises to a high level in early spring, as shown by the record of of this well in Chapel Hill, N. C. 
Table 2.-Concentrations of chemical constituents and their characteristic effects on water use in the region

[Concentration in parts per million except as indicated. Occurrence, where noted, is given in parenthesis after concentrations ]

\begin{tabular}{|c|c|c|}
\hline Constituents & Concentration & Characteristic effects on water use \\
\hline Silica $\left(\mathrm{SiO}_{2}\right) \ldots$ & $\begin{array}{l}\text { Rarely less than } 15 \text { or more } \\
\text { than } 45 \text {, commonly } 20 \text { to } 35 \text {. }\end{array}$ & $\begin{array}{l}\text { Forms hard scale in pipes and boilers } \\
\text { but not normally a serious problem } \\
\text { in the region. }\end{array}$ \\
\hline Iron $(\mathrm{Fe})$ & $\begin{array}{l}\text { Commonly less than } 0.3 \text { in } \\
\text { natural water, but corrosion } \\
\text { of iron pipes from water } \\
\text { with pH less than } 6.8 \text { causes } \\
\text { a fairly common iron prob- } \\
\text { lem. }\end{array}$ & $\begin{array}{l}\text { More than } 0.3 \mathrm{ppm} \text { stains laundry, } \\
\text { utensils, and fixtures reddish brown. }\end{array}$ \\
\hline Calcium (Ca) and & & \\
\hline magnesium $(\mathrm{Mg})$ & $\begin{array}{l}\text { Rarely less than } 5 \text { or more } \\
\text { than } 60 \text { (commonly } 5 \text { to } 20 \\
\text { in water beneath light- } \\
\text { colored soils and } 15 \text { to } 50 \text { in } \\
\text { water beneath dark-colored } \\
\text { soils). }\end{array}$ & $\begin{array}{l}\text { Cause most of the hardness and scale- } \\
\text { forming properties of water. (See } \\
\text { hardness below.) }\end{array}$ \\
\hline Bicarbonate $\left(\mathrm{HCO}_{3}\right)$ & $\begin{array}{l}\text { Rarely less than } 15 \text { or more } \\
\text { than } 150 \text {, commonly } 30 \text { to } \\
100 .\end{array}$ & $\begin{array}{l}\text { Concentrations in region are not gen- } \\
\text { erally high enough to cause trouble. }\end{array}$ \\
\hline Sulfate $\left(\mathrm{SO}_{4}\right)$ & $\begin{array}{l}\text { Rarely less than } 1 \text { or more } \\
\text { than } 100 \text {, commonly } 1 \text { to } 40 \text {. }\end{array}$ & $\begin{array}{l}\text { Concentrations in region are not gen- } \\
\text { erally high enough to cause trouble. }\end{array}$ \\
\hline Chloride (Cl) & $\begin{array}{l}\text { Rarely less than } 1 \text { or more } \\
\text { than } 40, \text { commonly } 1 \text { to } 20 \text {. }\end{array}$ & $\begin{array}{l}\text { Salty taste to water having mcre than } \\
\text { a few hundred parts per million. }\end{array}$ \\
\hline Fluoride (F) & $\begin{array}{l}\text { Rarely more than } 1 \text {, commonly } \\
0.0 \text { to } 0.6 \text {. }\end{array}$ & $\begin{array}{l}\text { Concentration between } 0.6 \text { anc } 1.7 \mathrm{ppm} \\
\text { in water retards decay of teeth, but } \\
\text { amounts in excess of } 1.5 \mathrm{ppm} \text { may } \\
\text { cause mottled enamel of teeth. }\end{array}$ \\
\hline Nitrate $\left(\mathrm{NO}_{3}\right)$ & $\begin{array}{l}\text { Rarely more than } 20, \text { com- } \\
\text { monly less than } 10 .\end{array}$ & $\begin{array}{l}\text { Where concentration is greater than } \\
20 \mathrm{ppm} \text {, contamination from sewage } \\
\text { may be suspected. Water of con- } \\
\text { centrations greater than } 45 \mathrm{ppm} \\
\text { may be harmful to babies. }\end{array}$ \\
\hline Dissolved solids _..... & $\begin{array}{l}\text { Total of all mineral matter } \\
\text { rarely exceeds } 250 \text {, commonly } \\
70 \text { to } 150 .\end{array}$ & $\begin{array}{l}\text { Water containing more than } 1,000 \mathrm{ppm} \\
\text { of dissolved solids is unsuitable for } \\
\text { most purposes. }\end{array}$ \\
\hline Hardness as eq & & \\
\hline $\mathrm{CaCO}_{3}--$ & $\begin{array}{l}\text { Rarely less than } 10 \text { or more } \\
\text { than } 150 \text { (commonly } 10 \text { to } \\
50 \text { in water beneath light- } \\
\text { colored soila and } 40 \text { to } 200 \\
\text { in water beneath dark- } \\
\text { colored soils). }\end{array}$ & $\begin{array}{l}\text { Causes consumption of soap before } \\
\text { lather will form. Hard water forms } \\
\text { scale in boilers and hot water } \\
\text { heaters. Water whose hard iess is } \\
\text { less than } 60 \mathrm{ppm} \text { is considered soft; } \\
61 \text { to } 120 \mathrm{ppm} \text {, moderately hard; } \\
121 \text { to } 180 \mathrm{ppm} \text {, hard; more than } \\
180 \text { ppm, very hard. }\end{array}$ \\
\hline pH & $\begin{array}{l}\text { Rarely less than pH of } 5.5 \text { or } \\
\text { more than } 7.5 \text { (commonly } \\
5.5 \text { to } 6.8 \text { in water beneath } \\
\text { light-colored soils and } 6.8 \\
\text { to } 7.5 \text { in water beneath } \\
\text { dark-colored soils). }\end{array}$ & $\begin{array}{l}\text { Values less than } 7.0 \text { indicate acidity, } \\
\text { and corrosiveness of water gen- } \\
\text { erally increases with decreasing } \\
\text { pH. }\end{array}$ \\
\hline
\end{tabular}


at the end of the year is at about the same level as at the beginning of the year. Wells drilled into rock may, when pumped at full capacity, yield slightly less during the driest part of the year when the water table is low. Yet there appears to be no evidence to support the general belief that the water table has been declining during recent years.

\section{CHEMICAL QUALITY OF THE WATER}

In comparison with ground water in widely scattered regions of the world, the water in the Piedmont and Blue Ridge provinces ranks among the best in chemical quality. (See table 2.) Most of the water is low in total dissolved solids and is generally soft, but some is moderately hard.

Iron in water is the most common complaint. As little as $0.4 \mathrm{ppm}$ (parts per million) will cause a red stain on plumbing fixtures. About 5 of every 10 wells yield water with less than $0.3 \mathrm{ppm}$ of iron. About 4 of 10 wells yield water with just enough iron to cause a slight stain, and about 1 of 10 wells yields water that has considerable iron. Some iron problems result when iron is dissolved from rocks, and other problems result when water, moving through iron pipes, consequently picks up a brown iron stain by corrosion. It is important to determine the source of the iron, whether dissolved from the rocks or from the pipes, before methods for its removal are employed. Most of the water is satisfactory for use without any type of treatment (table 2). Yet an analysis of the water should be made as soon as a well is drilled to determine if treatment is necessary. It is not possible to determine the quality of water before a well is drilled.

\section{CONTAMINATION OF GROUND WATER}

In view of the many hundreds of thousands of wells that are interspersed with about an equal number of septic tanks and other waste sites, it is proper to give serious attention to the possibility of contaminating an individual water supply. The tendency for ground waterand contaminants that might be in it-to move naturally from upland areas toward stream valleys offers help in planning wells and waste sites to avoid contamination. A well that is pumped may modify the natural movement of water and draw contaminated water toward it; this condition is more likely where the soil is thin or absent than where it is thick. Care should be taken to see that no water from the land surface can seep easily into the well around the casing. Not only is the well site important but so is the waste site. In most cases the chances of contaminated water from a waste site moving into a well are not easy to predict, but a few general statements can be made. For example, at a waste site (1) a deep water table is safer than a shallow water table, (2) thick soil is safer than thin soil or rock outcrops, (3) sandy soil with some clay may be better than a clean sandy soil or a sticky clay soil, and (4) a slope of both the land surface and the water table away from a well is better than one toward it.

The soil and weathered rock ar? generally effective in preventing waste materials from passing through to underlying rock fractures, but the combination of (1) certain types of wastes, (2) excessive quantities of disposed wastes, and (3) thin soils may result in contaminated water reaching bedrock fractures. Once in the bedrock fractures the contaminated water may move easily to water supplies. Only a small percentage of wells have been contaminated, but proper care in locating and constructing wells and waste sites must be taken to minimize the risk of contamination. Minimum standards specified by health officials, such as those relating to permeability of the soil, distance between a well and a waste site, and depth of the water table, must be followed.

\section{GENERAL STATEMENTS ABOUT GROUND WATER IN THE REGION}

1. Ground water may be considered as occurring in an underground reservoir, the water being held in the open spaces of the rock materials. The water table, representing the top of the reservoir, generally lies in the clay, or disintegrated rock materials. In the lower part of the reservoir, water occurs in interconnecting fractures in bedrock; the fractures diminish in number and size with increasing depth. Water enters the fractures by seeping through the overlying clay, and drilled wells draw water from these fractures. The source of this water is precipitation in the general area of a well and not in some remote place.

2. A layer of residual soil and weathered rock lies on the fresh rock in most places; the thickness of the soil and weatlered rock ranges from zero to slightly mors than 150 feet. 


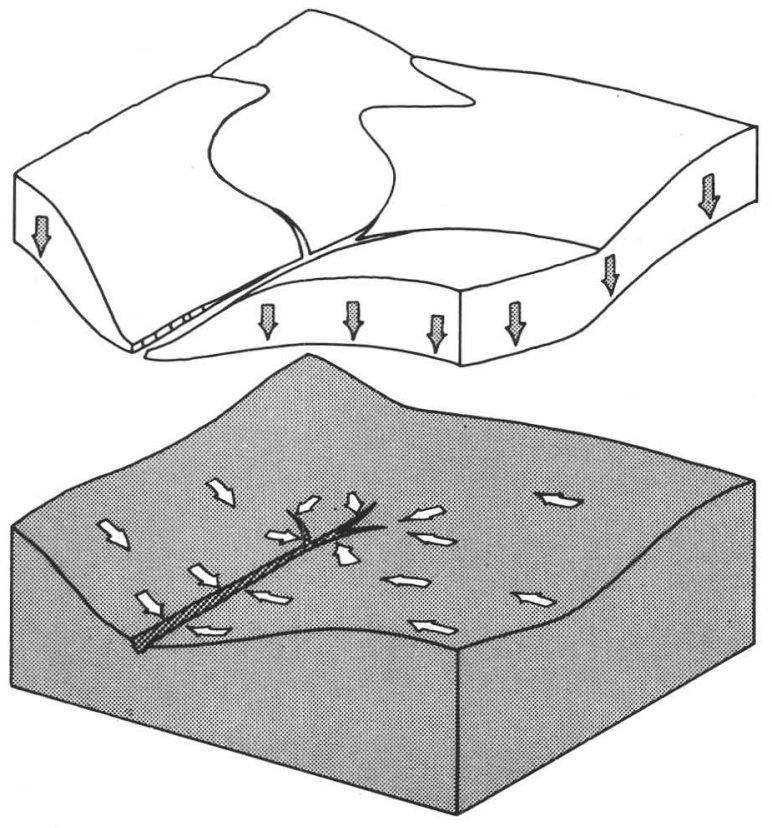

Figure 12. -Dry zone (above water table) lifted up to show water table or surface of saturated zone. Movement of water (arrows) tends to be downward in the dry zone and lateral toward streams in the saturated zone.

3. The water table has a hill and valley relation that approximately conforms with surface topography, although the water table is somewhat flatter. (See fig. 12.) For example, a creek or river is the surface expression of the water table in a valley, but beneath a hill the water table may be 30 to 70 feet below the ground surface. Ground water, like surface water, has the tendency to drain away from the hills to the valleys. This tendency helps in planning the location of wells in relation to other wells and to sources of possible contamination.

4. A close network of streams prevails, and in most places on an upland area a perennial stream is less than 1 mile away.

5. Toward the streams is a continuous flow of ground water. Some of the outflowing ground water is used up by evaporation and by transpiration of plants in the valley areas; the remainder of the water discharges as small springs and as bank and channel seepage into the streams.

6. The natural movement of ground water is relatively short and is almost everywhere restricted to the zone underlying the gross topographic slope extending from a particular land-surface divide to the adjacent streams.
7. In ideal cases the pumping of a well causes the water table to be depressed smoothly in the shape of an inverted cone, the apex of the cone being in the well; however, the erratic distribution of rock fractures and the contrasting nature of permeability between rock fractures and overlying soils cause the depressed part of the water table to extend unevenly around a well. Where two heavily pumped wells are within a few hundred feet of each other, there is a strong likelihood of some interference of pumping level between the two, but in most cases there is not any appreciable interference between low-yielding wells a few hundred feet apart. From a pumped well the depressed part of the water table rarely extends beneath a perennial stream or beneath a hilltop to a slope on the opposite side. Well interference is local, and there is no regional lowering of the water table because of pumping.

8. The relation of the depth of a well to yield of the aquifer is not simple. In spite of some beliefs, water already available to a well is rarely lost by drilling deeper; therefore, there is always a chance of getting a larger supply by increasing the depth of the well. Yet this chance becomes poorer as the well deepens because the interconnecting fractures and the ability of the rocks to store and transmit water decrease significantly with depth. More than 90 percent of all ground water occurs in the first 100 feet below the water table. Generally two wells 200 feet deep each will yield more water than one well 400 feet deep.

9. The relationship of topography to yield is emphasized. The great majority of wells are located on hills or smooth upland slopes because of convenience and because these locations appear safe from sources of contamination. Yet the percentage of low-yielding wells is much greater on hills and upland convex slopes than in lowlands or draws (concave slopes that lead upward from a valley to a saddle or sway-backed position in a ridge). Steep-sided depressions, such as gullies and ravines, should not be considered acceptable sites for wells.

10. In general, wells are more productive and tend to have a more stable year-round yield where there is a thick mantle of soil than where bare rock crops out. The presence of a soil cover and the absence of rock outcrop 
suggest that water moves downward into the rock and is not readily shunted toward the adjacent valley; in fact, the soil cover suggests that interconnecting rock fractures are available to store water and to transmit it to wells. Where there is a good soil cover, the water table generally lies in it; therefore, the storage capacity in the vicinity is much greater than where bare rock is exposed and where the only water in storage is in the rock fractures that might be quickly drained.

11. Simple clear-cut statements about the water-yielding properties of the various types of rocks are not easy to make. There are many varieties of igneous and metamorphic rocks, but for a discussion of their groundwater properties they may be grouped as follows: (1) Somewhat massive igneous rocks, such as granite, and (2) metamorphic rocks, such as schists, gneisses, and slates, which may show an alinement of minerals or an alinement of cleavage planes or openings along which water may move. In some places a type of rock may have distinctive waterbearing characteristics, but, if so, it is also likely to show distinctive topographic and soilmantle features. Topography and soil-mantle features are readily observed and may be used as criteria for predicting the wateryielding potential of a well site, whereas the water-bearing characteristics of a type of rock by itself may be obscure. At any rate, there are too many complex factors involved to justify generalizations about the yield of wells in individual types of rock.

12. Whenever water is pumped from a well, the water level is lowered in and around the well. The drawdown increases with an increase in the rate of pumping, although this relation is not simple. For example, a well yielding $20 \mathrm{gpm}$ with a drawdown of 50 feet will not double its yield by increasing the drawdown to 100 feet. Instead, it will yield less than $40 \mathrm{gpm}$ and perhaps no more than 25 to $30 \mathrm{gpm}$ with a drawdown of 100 feet.

13. Some wells that are pumped heavily tend to decline gradually in yield. This fact may be due to the following circumstances. The size and setting of a pump are determined from a short bailer or pumping test when the well is completed. Such a short test may not indicate the long-term yield of the well because the first water is withdrawn form storage in the rock materials, and many hours, days, or even months may pass before there is a stable adjustment between the amount of water that the fractures can feed into the well and the amount of water available to drain through the overlying clay into the fractures feeding the well. Failure to have knowledge of water-level fluctuations as a result of pumping is the cause of many well problems and of the erroneous conclusion that well supplies are not dependable. If a well tends to have an unstable yield, it is probably overpumped. A reduction in the rate of pumping and consequently a raising of the water level will result in a perennially safe yield. Constant pumping at a moderate rate does not damage a well.

14. There is a tendency for rocks underlying a light-colored soil to yield water that is low in dissolved mineral matter and is soft. On the other hand, rocks underlying darker soils (dark red, brown, and yellow) tend to yield water that is slightly hard, or hard, and that may contain objectionable amounts of iron.

15. Many people think that a shallow depth to the water table is an indication of a good yield of a potential well, but this is not a rule to follow. In fact, where the water table is only a few feet beneath the land surface on an upland area, the rock fractures may be so scarce that water may not be able to move downward in the rock; it is held near the ground surface and perhaps is shunted out to the land surface as a wet seepage spot on a steep slope.

16. There are many mistaken notions about the availability of ground water in the region. These notions arise from lack of knowledge of the occurrence and movement of ground water and of the behavior of wells. The common erroneous statement that a certain town in the region could not depend on well water stems from the existence of a limited number of wells; never has the underground reservoir beneath any town or city in the region been completely depleted of its water. There has been a tendency for towns of about 2,000 people to convert from well supplies to a treated surface-water supply; such conversion commonly occurs when the town requires more than 500,000 gallons of water per day, an amount which only a few wells in aggregate may not produce. Few towns have the experienced persons with diversified knowledge of wells and ground-water conditions to provide the good management comparable to that of municipal surface-water supplies. 


\section{SOURCES OF INFORMATION}

There are many sources of information about ground-water conditions in specific parts of the region. At least one agency in each State has cooperated financially with the U.S. Geological Survey, and these agencies have contributed in some way to the results of this report. Further information about reports published or work in progress may be obtained from the district offices of the Geclogical Survey in each State or from the respective State cooperating agencies. 
